\title{
Epstein-Barr virus in Hodgkin's lymphoma - immunohistochemical case series study
}

\author{
Mohammed S. Saeed \\ Department of Pathology, College of Medicine, University of Mosul.
}

(Ann. Coll. Med. Mosul 2009; 35(2): 93-103).

Received: $8^{\text {th }}$ May 2009; Accepted: $4^{\text {th }}$ Oct 2009.

\begin{abstract}
Objectives: 1- To determine the association between Hodgkin's lymphoma and Epstein-Barr virus. 2- To determine if it is related to certain age groups or specific histologic subtypes. 3- To compare the pattern with other developing or developed countries.

Methods: Biopsies of seventy cases with Hodgkin's lymphoma were collected from the pathology laboratories. The clinical data, including the patient's age, sex, site of lymph node affected and the histological classification according to the REAL classification, were retrieved from the pathologic reports. Immunoperoxidase stains for LMP-1 were performed on 40 cases.

Results: The mean age of all cases was 26.7 years, with a median of 25 years. There were 36 males and 34 females. The largest age group was seen in $15-40$ years accounting for $68.5 \%$. The third decade took the peak incidence $(21 / 70,30 \%)$. Nodular sclerosis Hodgkin's lymphoma was the most common subtype representing $58.5 \%$ of all the cases, followed by mixed cellularity ( $37.2 \%$ of cases). The lymphocyte depleted subtypes in $2.8 \%$, whereas lymphocytic predominant seen in $1.4 \%$ of cases. Latent membrane protein-1 was observed in $37.5 \%$ of Hodgkin's lymphoma. The most frequent association was observed in lymphocytic depletion subtype (50\%), followed by mixed cellularity subtype (45\%). The least frequent association was in nodular sclerosis type (27.7\%). The highest rate of EBV expression was seen in the pediatric age group ( $<15$ years; $66.6 \%)$ and the lowest rate was among young adults (15-40 years; $26.9 \%$ ). Older age group ( $>40$ years) has a rate of EBV expression (50\%) which is higher than the young adult patients, but lower than the pediatric age group. Epstein-Barr virus positive cases were mostly males (73.3\%) compared to females (26.7\%).

Conclusion: Hodgkin's lymphoma in our locality, in comparison with earlier studies, shows changing pattern with a gradual trend to those of developed countries including peak age group and subtypes. Moreover, Epstein-Barr virus is seen in slightly more than one third of cases and mostly seen in childhood, mixed cellularity and lymphocytic depletion subtypes with a male predominance.
\end{abstract}

Keywords: Hodgkin's lymphoma, Epstein-Barr virus, LMP1, developed and developing countries.

الأهداف: أولا: لكثف العلاقة بين ورم الهوجكن اللمفاوي و فيروس ابشتاين-بار. ثانيا: تحديد علاقة الفيروس مع الفئات

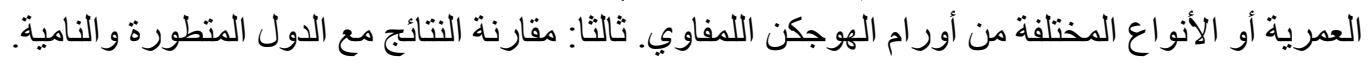

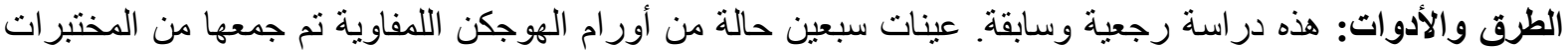

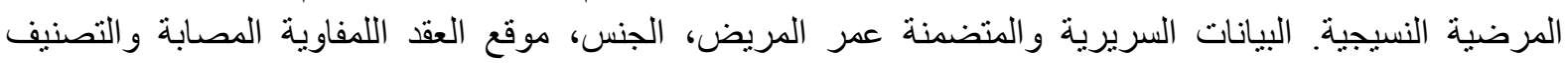
النسيجي للحالة اخذ من تقارير المريض. صبغة المناعية النسيجية للبروتين ألجداري المستترـا النم دراسته في في أربعين 


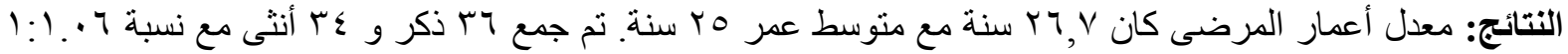

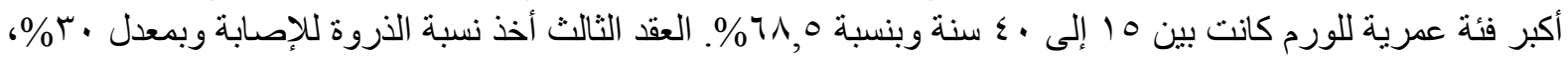

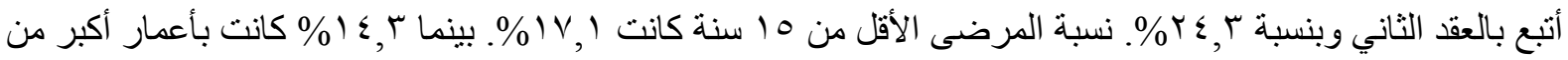

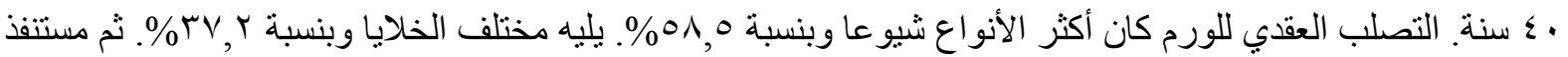

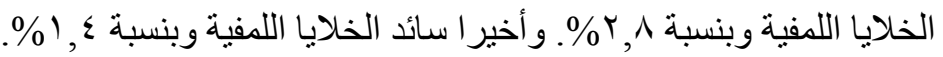

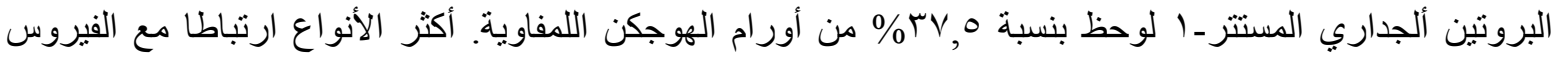

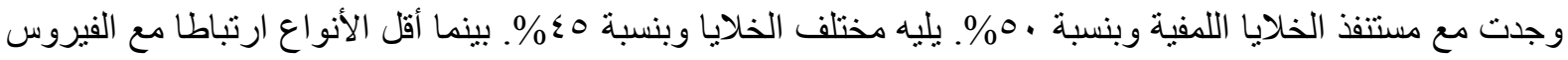

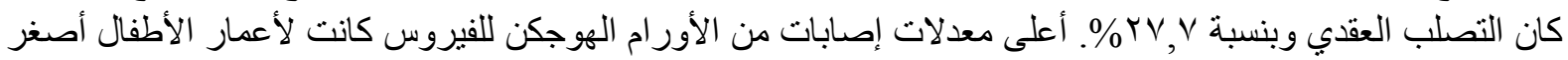

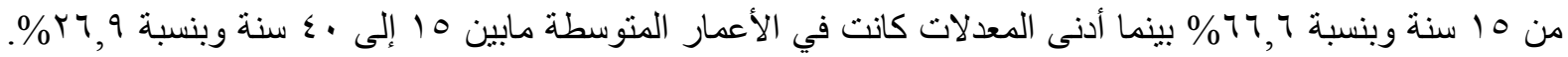

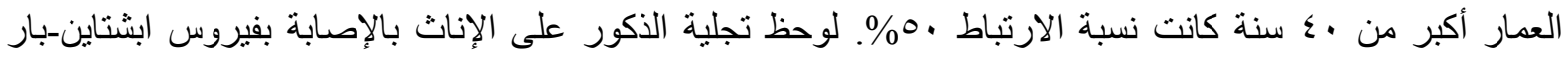

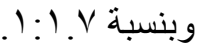

الاستتتاج: أور ام الهوجكن اللمفاوية في منطقتنا ومع مقارنتها بدراسات سابقة لوحظ تغير شكلي مع ميل تدرجي تجاه

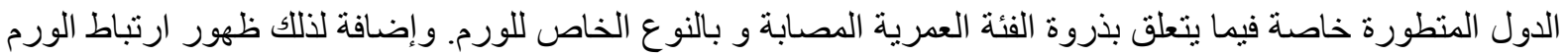
بالفيروس وبنسبة الثلث تقريبا خاصة في الأطفال و متعدد الخلايا و بخالبية ذكرية.

$\mathrm{H}$ odgkin's lymphoma (HL) is a heterogeneous condition that most probably comprises more than one etiological entity. As early as 1966 MacMahon proposed that Hodgkin's lymphoma might be caused by an infectious agent ${ }^{(1)}$. Epidemiological studies have indicated that many of the features of Hodgkin's lymphoma mimic those of an infectious process, including occurrence of disease in more than one member of the family of different ages, and clustering of cases in winter months ${ }^{(1)}$. EBV-associated disease is more common in low socioeconomic class and in children with maternal deprivation ${ }^{(2-4)}$.

The first evidence that suggests the relationship between Hodgkin's lymphoma and Epstein-Barr virus (EBV) was provided by the detection of raised antibody titres to EBV antigens in patients with Hodgkin's lymphoma when compared with patients with other lymphomas and, further, that these raised values preceded the development of Hodgkin's disease by several years ${ }^{(1,5)}$. In addition, there is a specific association between EBVassociated $\mathrm{HL}$ in young adults and previous infectious mononucleosis with a relative risk of developing Hodgkin's lymphoma relative to those with no previous history, was shown to range between 2.0 to $5.0^{(1,6)}$.
Studies suggest that the EBV is associated with approximately one third of cases in developed countries, and this association is believed to be casual ${ }^{(7,8)}$. Whereas higher rates of association was reported in developing countries ${ }^{(9-14)}$.

EBV is more often associated with mixed cellularity $\mathrm{HL}$ than with nodular sclerosis type, and in children and older adults than in young adults ${ }^{(15-18)}$. Also it is more in males than females and more in Asians and Hispanics than whites or blacks ${ }^{(19)}$.

According to the age of the patients and EBV association: 4-disease models have been recognized, one EBV-negative group of cases, which accounts for the young adult peak in disease incidence as seen in developed countries, and three EBV-positive subgroups. The latter includes a childhood group, accounting for almost all cases of $\mathrm{HL}$ in early childhood; a young adult group, and an older adult group, which results from loss of the normal balance between latent EBV infection and host immunity (figure 1$)^{(6,20,21)}$.

EBV is an extremely efficient transforming agent infecting the Hodgkin/Reed Stenberg's (HRS) cells. The EBV genome is composed of linear-double-stranded DNA which code for different types of latent proteins. Six are nuclear antigens (EBNA1, 2, 3A, 3B, 3C, EBNA-LP), and three latent membrane 
proteins (LMP1, LMP2A, LMP2B). LMP1 is the major transforming protein of EBV and is the only latent protein that can transform rodent fibroblast ${ }^{(22)}$. Expression of LMP1 appears to mimic a constitutively active CD40 receptor ${ }^{(23)}$. Both CD40 and LMP1 bind tumor necrosis factor (TNF) receptor-associated factors (TRAFs), initiating a signaling cascade that leads to activation of transcription factors NFkappa B, AP-1 and STAT ${ }^{(22,24-29)}$. By providing these CD40-like signals, it is conceivable that LMP1 allows EBV-infected HRS cells upregulate various antiapoptotic genes including bcl-2, mcl-1 \& cytokine that bypass a germinal center checkpoint and escape apoptosis $^{(27,30-33)}$.

Older adults and children who are EBV positive have a poor prognosis possibly reflecting a poor immune status, which in turn means that those patients may tolerate disease and its treatment less well ${ }^{(3,34)}$.

The aims of this study were first, to determine the association between Hodgkin's lymphoma and Epstein-Barr virus. Second, to determine if it is related to certain age groups or specific histologic subtypes. Third, to compare the pattern with other developing or developed countries.

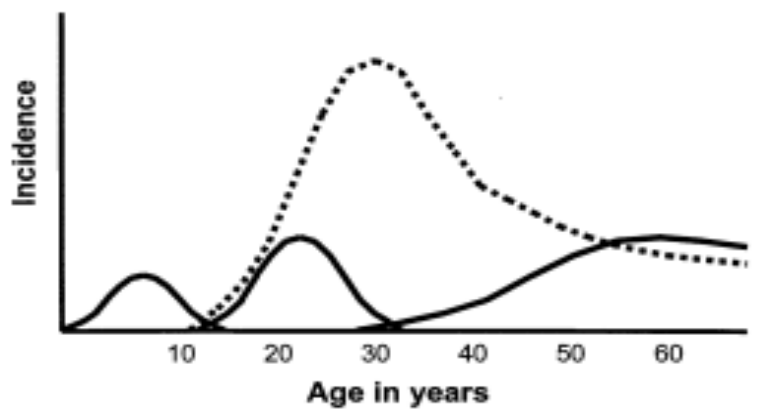

Figure (1): Four disease model of Hodgkin's lymphoma. Solid line is EBV-associated cases (three groups first below 10 years, second young adult between 14 and 34 years, the third are more than 55 years of age). Dashed line is non-EBV associated cases (one peak at young adults mainly seen in developed countries).

\section{Methods}

This is a retro- and prospective study, conducted between 2007 - 2009. Seventy cases of Hodgkin's lymphoma were collected with their clinical data including age, sex, site of lymph node affected and the histological classification according to the REAL scheme). To some of the cases immunohistochemical stains including (CD15, CD30, CD43 and CD20) have been also applied as complementary tests.

Immunoperoxidase staining for LMP-1 was performed on 40 cases in this study. Three micron thick sections were cut from each selected paraffin block onto silane-coated slides; sections were then dewaxed, rehydrated to distilled water. Antigen retrieval was carried out by autoclaving at $95-99^{\circ} \mathrm{C}$, for 20 minutes by a retrieval solution. The sections were then allowed to cool for at least 20 minutes, followed by washing 3 times each for 5-minutes in changes of phosphate buffered saline (PBS). Endogenous peroxidase activity was blocked by placing sections in $3 \%$ hydrogen peroxide for 5 minutes and washed in 3 changes of distilled water. Sections were incubated with 1:100 diluted primary antibodies against LMP1 (Dako, Monoclonal Mouse Anti-Epstein-Barr virus, LMP1, Clone C4.1-4) for 30 minutes, followed by washing twice in 5-minutes changes of PBS. The sections were incubated for 30 minutes with secondary Dako envision antibody. Sections were washed twice by PBS and visualized using diaminobenzidine (DAB). Finally, the sections were lightly counterstained with hematoxylin, dehydrated and mounted. Negative control sections were treated in the same way except for the use of a negative control (Dako Mouse IgG1) instead of primary antibody. Positive control sections were taken from a positive case and were done in each run.

\section{Results}

Clinical findings: From the 70 collected cases, the ages of the patients ranged from 280 years with a mean of 26.7 years, and a median of 25 years. There were 12 patients (17.1\%) under 15 years of age. Ten cases 
(14.3\%) were above 40 years of age. Whereas the greatest group of Hodgkin's lymphoma was seen in young adult group (15 - 40 years) 48 patients $(68.5 \%)$. The third decade took the peak incidence $(21 / 70,30 \%)$, followed by the second decade $(17 / 70,24.3 \%)$. There were 36 males and 34 females with male to female ratio of 1.06:1.

Histopathologic findings: Nodular sclerosis Hodgkin's lymphoma was the most common subtype in this series representing 58.5\% $(41 / 70)$ of all the cases; mixed cellularity represents $37.2 \% \quad(26 / 70)$, lymphocyte depleted subtype represents $2.8 \%$ (2/70), and lymphocytic predominant is reported in $1.4 \%$ (1/70), figure 2.

In patients $<15$ years old, the most frequent subtype was mixed cellularity (66.6\%), followed by nodular sclerosis $(25.0 \%)$. The most common subtype in patients aged 15-40 years was nodular sclerosis (70.8\%), followed by mixed cellularity (27.1\%), and then by lymphocytic predominant (2.1\%). Patients $>40$ years, the most common type was mixed cellularity $(50 \%)$, followed by nodular sclerosis (40\%), then lymphocytic depletion subtypes (10\%) (Table 1).

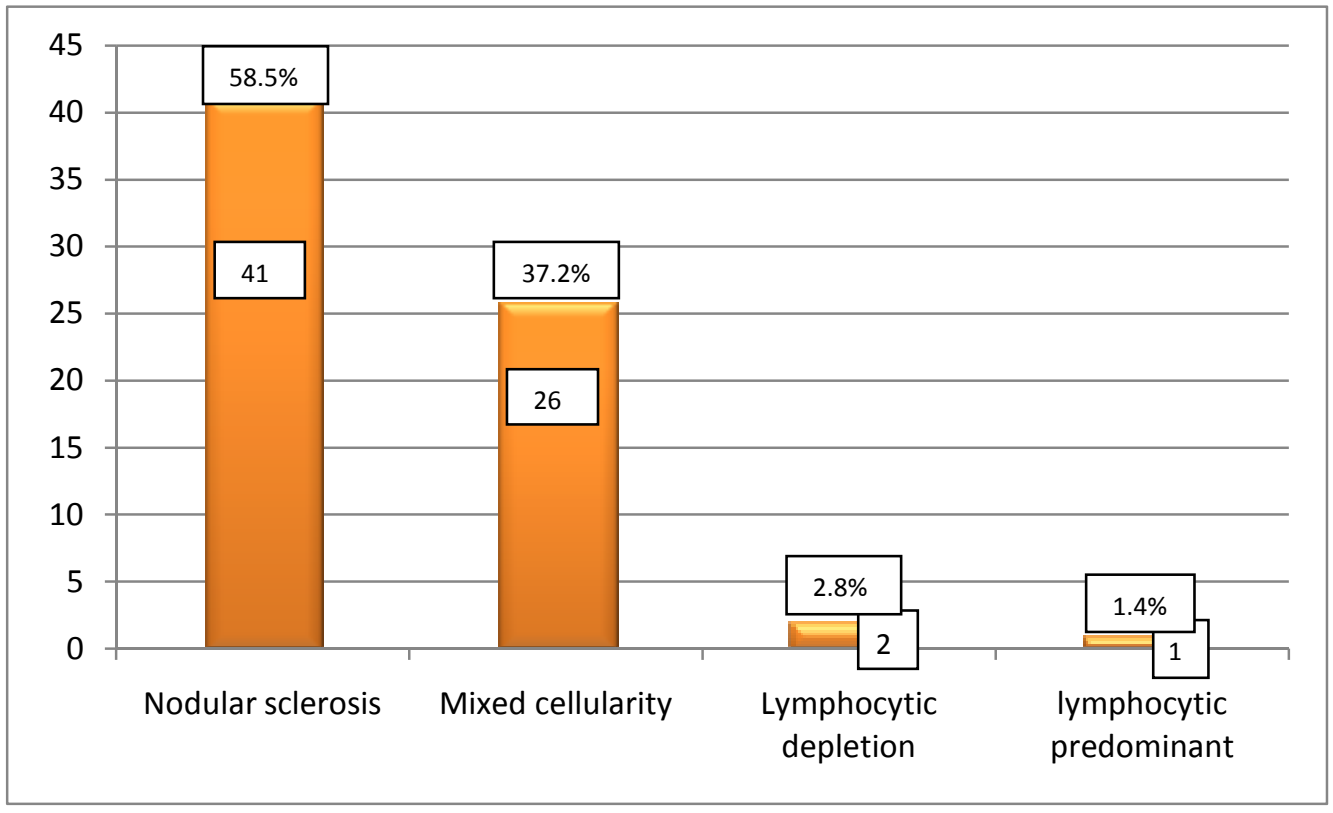

Figure (2): The percentage of various subtypes of Hodgkin's lymphoma.

Table (1): Distribution of Hodgkin's lymphoma subtypes according to the main age groups.

\begin{tabular}{|c|c|c|c|c|c|}
\hline Age group & Mixed cellularity & Nodular sclerosis & $\begin{array}{l}\text { Lymphocytic } \\
\text { depletion }\end{array}$ & $\begin{array}{l}\text { Lymphocytic } \\
\text { predominant }\end{array}$ & Total \\
\hline & No. / \% & No. / & No. / \% & No. I & No. I \\
\hline$<15$ & $(66.6)$ & $(25.0)$ & $(8.3)$ & $(0.0)$ & 17.1 \\
\hline $15-40$ & (27.1) & $(70.8)$ & $(0.0)$ & $(2.1)$ & 68.5 \\
\hline$>40$ & $(50.0)$ & $(40.0)$ & $(10.0)$ & $(0.0)$ & 14.3 \\
\hline Total & $(37.2)$ & $(58.5)$ & $(2.8)$ & (1.4) & 100.0 \\
\hline
\end{tabular}


Epstein-Barr virus status: Positive LMP-1 staining was seen in the cytoplasm and cell membranes of Hodgkin's/Reed-Sternberg cells. It was observed in 15 out of 40 cases (37.5\%) of Hodgkin's lymphoma (figure 3).
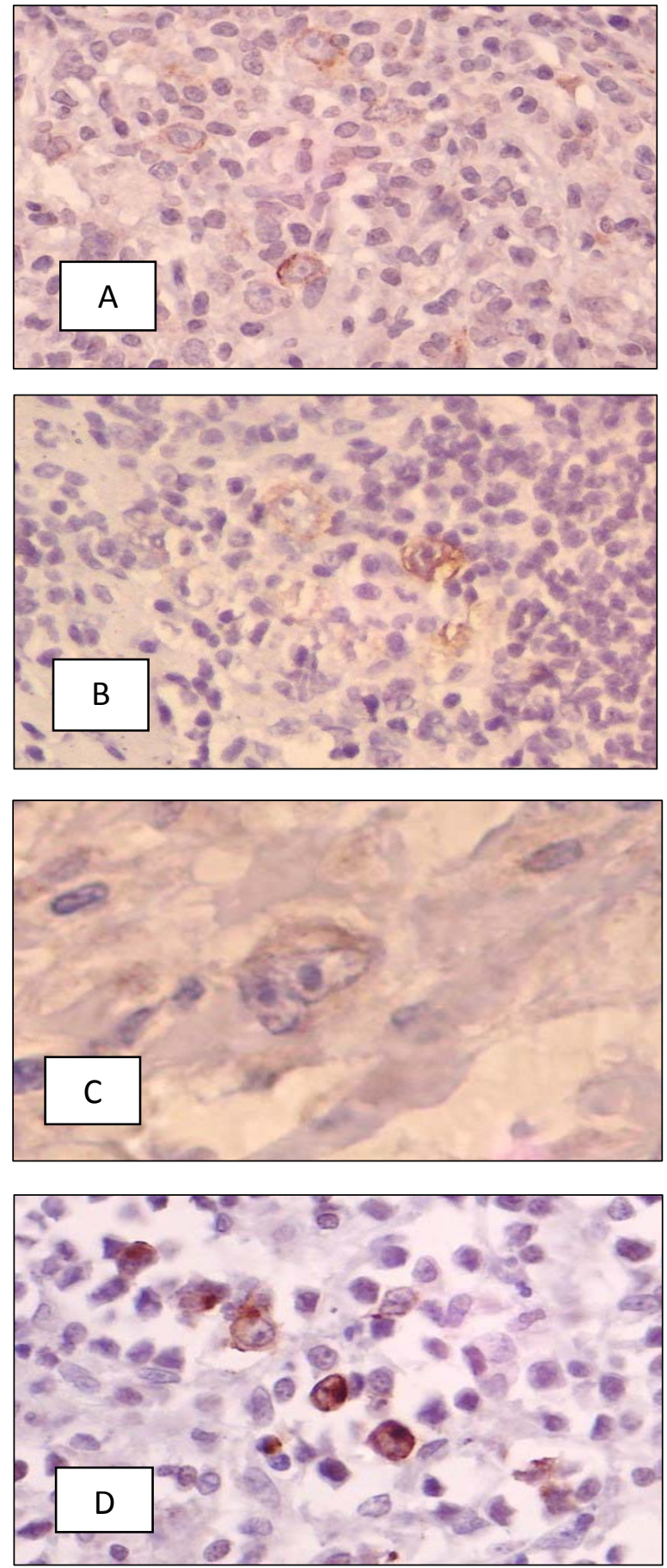

The most frequent association was in cases of lymphocytic depletion subtype (1/2; 50\%), followed by mixed cellularity subtype (9/20; $45 \%)$. The least frequent association was observed in nodular sclerosis type (5/18; $27.7 \%$ ) as shown in table (2).
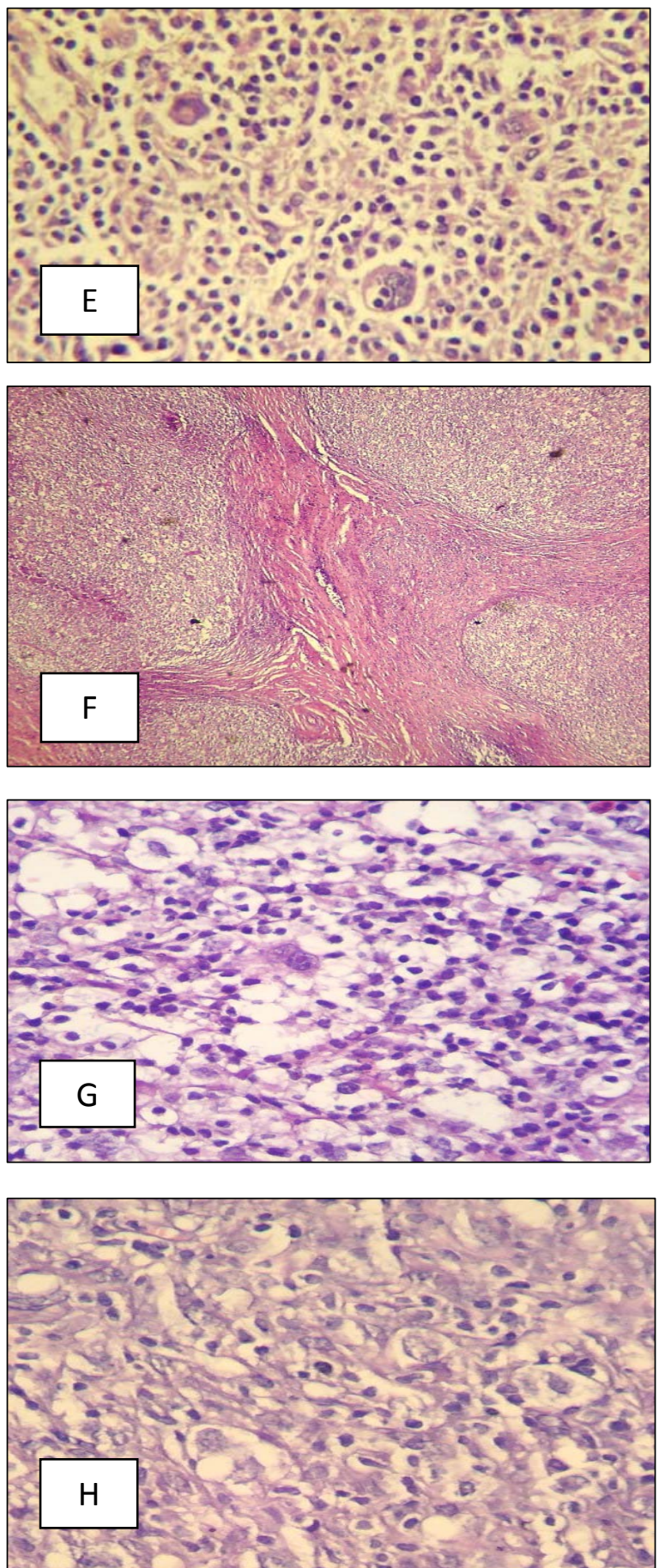

Figure (3): A, B, C, \& D show positive LMP-1 staining seen in the cytoplasm and cell membranes of Hodgkin's/Reed-Sternberg cells. H \& E stain of different subtypes of Hodgkin's lymphoma, E (MCHL), F (NSHL), G (Classical R-S cell), H (LDHL). 
Table (2): Epstein-Barr virus association with various types of Hodgkin's lymphoma.

\begin{tabular}{|l|c|c|c|c|}
\hline \multirow{2}{*}{ Histological Types } & LMP-1 Positive & LMP-1 Negative & \multicolumn{2}{|c|}{ Total } \\
\cline { 2 - 5 } & No. & No. & Total No. & of Positivity \\
\hline Lymphocytic depletion & 1 & 1 & 2 & 50 \\
\hline Mixed cellularity & 9 & 11 & 20 & 45 \\
\hline Nodular sclerosis & 5 & 13 & 18 & 27.7 \\
\hline Total & 15 & 25 & 40 & 37.5 \\
\hline
\end{tabular}

The frequency of EBV expression in relation to the age is shown in table (3). The highest rate of EBV expression was seen in the pediatric age group (<15 years; 66.6\%) and the lowest rate was among the young adults (15-40 years; $26.9 \%)$. The older adult ( $>40$ years) have a rate of EBV expression (50\%) in between the 2 groups (higher than the young adult patients, but less than the pediatric age group).

Epstein-Barr virus positive cases were mostly in males $(11 / 15 ; 73.3 \%)$ compared (4/15; $26.7 \%)$ females.

\section{Discussion}

Most studies on Hodgkin's lymphoma have shown epidemiological differences between developed and developing countries. Correa and O'Conor introduced the concept of at least three epidemiological patterns of Hodgkin's lymphoma based upon country of residence. A type I pattern is characterized by relatively high incidence rates in male children, low incidence in the third decade, and a second peak of high incidence in older age groups. The histological subtypes are often those with a less favorable prognosis, usually either mixed cellularity or lymphocytic depletion. This pattern prevails in developing countries. Type III is the converse of the type I pattern, being characterized by low rates in children and a pronounced initial peak in young adults. The more favorable subtype of nodular sclerosis is common and this pattern is typical of developed countries. Type II is an intermediate pattern, and reflects a transition between type I and type III. Correa and O'Conor interpreted these data as the result of the interplay of environmental and host factors influencing the natural history of a single disease ${ }^{(1,35)}$.

In this study, young adult group (15-40 years) was the largest age group, and the third decade represented the peak incidence. There is predominance of nodular sclerosis subtype, which accounts for $58.5 \%$ of Hodgkin's lymphoma. There is relatively equal ratio between male and female (1.06:1). Al-Dewachi and Al-Irhayim ${ }^{(36)}$ in a study done in Mosul in 1995 have observed the bimodal age distribution of the disease, with a peak age incidence coming one decade earlier than those reported in the Western countries and found the predominance of male sex in three histological types of mixed cellularity, lymphocytic depletion and lymphocytic predominance, while nodular sclerosis showed an almost equal gender distribution. In a more recent study done in Mosul in 2007, Abbas ${ }^{(37)}$ found an increasing incidence of nodular sclerosis cases with the peak age incidence in the second decade, followed by the third decade. Comparing our findings with these previous studies shows the gradual changing trends of Hodgkin's lymphoma to that of developed countries as described previously by

Table (3): Distribution of Epstein-Barr virus in Hodgkin's lymphoma according to main age groups.

\begin{tabular}{|l|c|c|c|c|}
\hline \multirow{2}{*}{ Age group (years) } & LMP-1 Positive & LMP-1 Negative & \multicolumn{2}{|c|}{ Total } \\
\cline { 2 - 5 } & No. & No. & Total No. & \% of Positivity \\
\hline$<15$ & 4 & 2 & 6 & 66.6 \\
\hline $15-40$ & 7 & 19 & 26 & 26.9 \\
\hline$>40$ & 4 & 4 & 8 & 50 \\
\hline Total & 15 & 25 & 40 & 37.5 \\
\hline
\end{tabular}


Correa and O'Conor ${ }^{(1,35)}$. Similar findings have been documented from Kuwait, KSA \& United Arab Emirates ${ }^{(38-40)}$.

Moreover EBV association studies have revealed differences between developed and developing countries with higher EBV related Hodgkin's lymphoma cases in developing countries. In an attempt to summarize the literature data (Table 4), we found that most North American and European countries have 20-40\% EBV association, as opposed to much higher rates that may reach more than $90 \%$ in some of Far East and South American reports.

Results from this study confirmed the presence of EBV in the neoplastic cells of the Hodgkin's lymphoma cases. The proportion of HD cases associated with EBV was $37.5 \%$. Such figures appear to be lower than those reported in Far East, South America and some of Middle East Countries while similar to those reported in Jordan, Saudi Arabia, South Israel, North America and European Countries.

Takeuchi et $\mathrm{al}^{(58)}$ have recorded a decreasing trend of EBV positive nodular sclerosis Hodgkin's disease during the last 4 decades, whereas Clarke et $\mathrm{al}^{(34)}$ have observed that EBV positive Hodgkin's lymphoma patients are less likely to have nodular sclerosis histology. Flavell et $\mathrm{al}^{(59)}$ have suggested that Hodgkin's lymphoma of childhood and elderly is commonly EBV associated, whereas the adult Hodgkin's disease is not significantly associated with EBV infection. All these explain the low percentage of EBV in our locality.

Table (4): Summary of literature on Epstein-Barr virus association with Hodgkin's lymphoma stained by Immunoperoxidase for LMP-1.

\begin{tabular}{|c|c|c|c|c|}
\hline Study & Country & $\%$ of EBV & $\%$ of + in $M C$ & $\%$ of + in NS \\
\hline Alkuraya et al ${ }^{41}$ & KSA & 28.6 & 52.4 & 26.1 \\
\hline Yilmaz et $^{4{ }^{42}}$ & Turkey & 61.5 & 91.3 & NP \\
\hline Almasri et $\mathrm{al}^{43}$ & Jordan & 39.1 & 52.9 & 25 \\
\hline Makar et al $^{44}$ & Kuwait & 56 & 45.5 & 37.3 \\
\hline Benharroch et $\mathrm{al}^{45}$ & South Israel & 30 & 45 & 21 \\
\hline Chang et $\mathrm{al}^{46}$ & USA & 24 & NP & NP \\
\hline 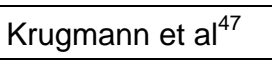 & Austria & 26 & NP & NP \\
\hline Pinkus et $\mathrm{al}^{48}$ & USA & 26 & 69 & 14 \\
\hline Enblad et $\mathrm{al}^{49}$ & Sweden & 27 & 38 & 23 \\
\hline Jarrett et al $^{7}$ & U.K & 33 & 60 & 23.8 \\
\hline Delsol et al ${ }^{50}$ & France & 34 & 58.2 & 10 \\
\hline Keresztes et $\mathrm{al}^{51}$ & Hungary & 43 & 50 & 35 \\
\hline Dirnhofer et al ${ }^{52}$ & Mexico & 61 & 75 & 56 \\
\hline Peh et $\mathrm{al}^{53}$ & Malaysia & 61 & 87 & 33.3 \\
\hline Zhou et $\mathrm{al}^{54}$ & China & 72 & NP & NP \\
\hline 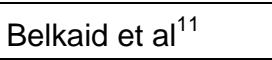 & Algeria & 72 & 77 & NP \\
\hline Karnik et al ${ }^{55}$ & South India & 82 & NP & NP \\
\hline Dinand et $\mathrm{al}^{56}$ & India & 90.3 & NP & NP \\
\hline Araujo et $\mathrm{al}^{57}$ & Brazil & About 100 & NP & NP \\
\hline
\end{tabular}

EBV- Epstein-Barr virus. MC- Mixed cellularity. NS- Nodular sclerosis. NP- Not provided 
Epstein-Barr virus positivity was related to the histologic subtypes of Hodgkin's lymphoma. The lymphocytic depletion and the mixed cellularity types were the most common subtypes associated with EBV. Only one fourth of the nodular sclerosis subtype had evidence of EBV association. These observations are in agreement with most data reported in the literature (Table 4).

Higher percentage of EBV positivity was observed in children below 15 years of age, followed by older adult group (> 40 years). Whereas the least association was seen in young adult age group. This is in agreement with many of the other studies $(7,11,15,19,24,43$, $44,46,53,54,59,60$ )

EBV associated with Hodgkin's lymphoma was seen in males more than in females, this is in concordance with many other similar studies $(7,19,44,47,60-62)$.

In conclusion, the data from this study and in comparison with earlier studies, show changing pattern of Hodgkin's lymphoma in our locality with a gradual trends to those of developed countries, including greatest age group, peak age incidence and subtypes. Moreover, Epstein-Barr virus is seen in slightly greater than one third of cases and mostly seen in childhood, mixed cellularity and lymphocytic depletion subtypes with a male predominance.

\section{References}

1. Flavell KJ and Murray PG. Hodgkin's disease and Epstein-Barr virus. J Clin Pathol: Mol Pathol 2000; 53: 262-269.

2. Flavell K, Constandinou C, Lowe D, et al. Effect of material deprivation on EpsteinBarr virus infection in Hodgkin's disease in the West Midlands. Br J Cancer 1999; 80: 604-608.

3. Flavell KJ, Biddulph JP, Powell JE, et al. South Asian ethnicity and maternal deprivation increase the risk of EpsteinBarr virus infection in childhood Hodgkin's disease. Br J Cancer 2001; 85: 350-356.

4. Gilchrist GS, Pollock BH, et al. Socioeconomic status, the Epstein-Barr virus and risk of Hodgkin's disease in children. Leuk Lymphoma 2001; 42 (Suppl 2): 40 .
5. Mueller N, Evans $\mathrm{A}$, Harris $\mathrm{NL}$, et al. Hodgkin's disease and Epstein-Barr virus: altered antibody pattern before diagnosis. N Engl J Med 1989;320:689-695.

6. Alexander FE, Lawrence DJ, Freeland J, et al. An epidemiologic study of index and family infectious mononucleosis and adult Hodgkin's disease (HD): evidence for a specific association with EBV +ve HD in young adults. Int J Cancer 2003;1: 298302.

7. Jarrett RF, Krajewski AS, Angus B, et al. The Scotland and Newcastle epidemiological study of Hodgkin's disease: impact of histopathological review and EBV status on incidence estimates. J Clin Pathol 2003; 56: 811-816.

8. Jarret RF. Epstein-Barr virus and Hodgkin's lymphoma. Epstein-Barr virus Report 1998; 5:77-85.

9. Ambinder RF, Browning PJ, Lorenzana I, et al. Epstein-Barr virus and childhood Hodgkin's disease in Honduras and the United States. Blood 1993; 81: 462-467.

10. Chang KL, Albujar PF, Chen YY, et al. High prevalence of Epstein-Barr virus in the Reed-Sternberg cells of Hodgkin's disease occurring in Peru. Blood 1993; 81: 496-501.

11. Belkaid MI, Briere J, Djebbara Z, et al. Comparison of Epstein-Barr virus markers in Reed-Sternberg cells in adult Hodgkin's disease tissues from an industrialized and a developing country. Leuk Lymphoma 1995; 17: 163-168.

12. Leoncini L, Spina D, Nyongo A, et al. Neoplastic cells of Hodgkin's disease show differences in EBV expression between Kenya and Italy. Int J Cancer 1996; 65: 781-784.

13. Monterroso V, Zhou $\mathrm{Y}$, Koo $\mathrm{S}$, et al. Hodgkin's disease in Costa Rica: a report of 40 cases analyzed for Epstein-Barr virus. Am J Clin Pathol 1998; 109: 618624.

14. Zhou XG, Hamilton-Dutoit SJ, Yan QH, et al. The association between Epstein-Barr virus and Chinese Hodgkin's disease. Int J Cancer 1993; 55: 359-363. 
15. Jarret RF, Armstrong AA, and Alexander FE. Epidemiology of Epstein-Barr virus and Hodgkin's lymphoma. ANN Oncol 1996; 7:S5-S10.

16. Pallesen G, Hamilton-Dutoit SJ, Rowe M, et al. Expression of Epstein-Barr virus latent gene products in tumor cells of Hodgkin's disease. Lancet 1991;337:320322.

17. Armstrong AA, Alexander FE, Paes RP, et al. Association of Epstein-Barr virus with pediatric Hodgkin's disease. Am J Pathol 1993;142:1683-1688.

18. Armstrong AA, Alexander FE, Cartwright $\mathrm{R}$, et al. Epstein-Barr virus and Hodgkin's disease: Further evidence for the three disease hypothesis. Leukemia 1998; 12 : 1272-1276.

19. Glaser SL, Lin RJ, Stewart ST, et al. Epstein-Barr virus associated Hodgkin's disease: epidemiologic characteristic in international data. Int J Cancer 1997; 70: 375-382.

20. Alexander FE, Jarrett RF, Lawrence D, et al. Risk factors for Hodgkin's disease by Epstein-Barr virus (EBV) status: prior infection by EBV and other agents. $\mathrm{Br} \mathrm{J}$ Cancer 2000; 82: 1117-1121.

21. Jarrett RF, Stark GL, Alexander FE, et al. Impact of tumor Epstein-Barr virus status on presenting features and outcome in age-defined subgroups of patients with classic Hodgkin lymphoma: a populationbased study. Blood 2005; 106 (7): 24442451.

22. Young LS and Murray PG. Epstein-Barr virus and oncogenesis: from latent genes to tumors. Oncogene 2003; 22:5108-5121.

23. Eliopoulos $A G$, and Rickinson $A B$. Epstein-Barr virus: LMP1 masquerades as an active receptor. Curr Biol 1998; 8: R196-R198.

24. Devergne O, Hatzivassiliou E, Izumi Km, et al. Association of TRAF1, TRAF2, and TRAF3 with an Epstein-Barr virus LMP1 domain important for B lymphocyte transformation: role in NF-kappa B activation. Mol Cell Biol 1996; 16: 70987108
25. Izumi KM, and Kieff ED. Epstein-Barr virus oncogen product latent membrane protein 1 engages the tumor necrosis factor receptor-associated death domain protein to mediate B lymphocyte growth transformation and activate NF-kappa B. Natl Acad Sci USA 1997; 94:12592-12597.

26. Kieser A, Kilger E, Gires O, et al. EpsteinBarr virus latent membrane protein 1 triggers AP-1 activity via the c-Jun Nterminal kinase cascade. EMBO J 1997; 16: 6478-6485.

27. Gires O, Kohlhuber F, Kilger E, et al. Latent membrane protein 1 of Epstein-Barr virus interacts with JAK3 and activates STAT proteins. EMBO J 1999; 18: 30643073.

28. Huen DS, Henderson SA, Croom-Carter $D$, et al. The Epstein-Barr virus latent membrane protein-1 (LMP1) mediates activation of NF-kappa B and cell surface phenotype via two effecter regions in its carboxy-terminal cytoplasmic domain. Oncogene 1995;10:549-60.

29. Mitchell T, and Sugden B. Stimulation of NF-kappa B-mediated transcription by mutant derivatives of the latent membrane protein of Epstein-Barr virus. J Virol 1995;69:2968-76.

30. Henderson S, Rowe M, Gregory C, et al. Induction of bcl-2 expression by EpsteinBarr virus latent membrane protein 1 protects infected B cells from programmed cell death. Cell 1991;65:1107-15.

31. Jarrett RF. Viruses and Hodgkin's lymphoma. Ann Oncol 2002; 13: 23-29.

32. Wang $S$, Rowe $M$, and Lundgren $E$. Expression of the Epstein Barr virus transforming protein LMP1 causes a rapid and transient stimulation of the $\mathrm{Bcl}-2$ homologue $\mathrm{Mcl}-1$ levels in B-cell lines. Cancer Res 1996;56:4610-13.

33. Rowe M, Peng-Pilon M, Huen DS, et al. Upregulation of bcl-2 by the Epstein-Barr virus latent membrane protein LMP1: a Bcell-specific response that is delayed relative to NF-kappa B activation and to induction of cell surface markers. J Virol 1994;68:5602-12. 
34. Clarke CA, Glaser SL, Dorfman RF, et al. Epstein-Barr virus and survival after Hodgkin's disease in a population-based series of women. Cancer 2001; 91: 15791587.

35. Almasri NM. Hodgkin's lymphoma in North Jordan, dose it have a different pattern?. Saudi Med J 2004; 25 (12): 1917- 1921.

36. Al-Dewachi HS, Al-Irhayim BA. Hodgkin's disease in North of Iraq. A study of 215 cases. JIMA 1995; 27 (2): 64-67.

37. Abbas RK. Immunohistochemical markers (CD30 Ki-1 and CD45 CLA) in Hodgkin's disease and non-Hodgkin's lymphoma. A thesis submitted to the scientific Council of pathology in partial fulfillment for the requirement of the degree of the fellowship of Iraqi Board for Medical Specialization in Pathology 2007; 26-29.

38. Makar RR, Saji T, and Junaid TA. EpsteinBarr virus expression in Hodgkin's lymphoma in Kuwait. Pathol Oncol Res 2003; 9: 159-165.

39. Al-Diab Al, Siddiqui N, Sogiawalla FF, et al. The changing trends of adult Hodgkin's disease in Saudi Arabia. Saudi Med J 2003; 24: 617-622.

40. Castella A, Joshi S, Raaschou T, et al. Pattern of malignant lymphoma in the United Arab Emirates - a histopathologic and immunologic study in 208 native patients. Acta Oncol 2001; 40: 660-664.

41. AL-Kuraya K, Narayanappa R, Al-Dayel F, et al. Epstein-Barr virus infection is not the sole cause of high prevalence for Hodgkin's lymphoma in Saudi Arabia. Leuk lymphoma 2006; 47 (4): 707-713.

42. Yilmz F, Uzunlar AK, Sogutcu $N$, et al. Hodgkin's disease and association with Epstein-Barr virus in children in Southeast Turkey. Saudi Med J. 2005; 26 (4): 571575.

43. Almasri NM, and Khalidi HS. Epstein-Barr virus expression in Hodgkin's disease in Jordan. Saudi Med J 2004; 25 (6): 770775.

44. Makar RR, Saji T, Junaid TA. Epstein-Barr virus expression in Hodgkin's lymphoma in Kuwait. Pathol Oncol Res 2003; 9 (3): 159-165.
45. Benharroch D, Brousset P, Goldstein J, et al. Association of the Epstein-Barr virus with Hodgkin's disease in Southern Israel. Int J Cancer 1997; 71 (2): 138-141.

46. Chang ET, Zheng T, Weir EG, et al. Aspirin and the Risk of Hodgkin's Lymphoma in a Population-Based CaseControl Study. JNCI 2004; 96 (4):305-315.

47. Krugmann J, Tzankov A, Gschwendtner A, et al. Longer failure-free survival interval of Epstein-Barr virus-associated classical Hodgkin's lymphoma: a single-institution study. Mod Pathol. 2003 Jun;16(6): 566573.

48. Pinkus GS, Lones $M$, Shintaku IP, et al. Immunohistochemical detection of Epstein-Barr virus-encoded latent membrane protein in Reed-Sternberg cells and variants of Hodgkin's disease. Mod Pathol 1994; 7: 454-461.

49. Enblad G, Sandvej K, Sundstrom C, et al. Epstein-Barr virus distribution in Hodgkin's disease in an unselected Swedish population. Acta Oncol 1999; 38: 425-429.

50. Delsol G, Brousset P, Chittal S, et al. Correlation of the expression of EpsteinBarr virus latent membrane protein and in situ hybridization with biotinylated BamHI$\mathrm{W}$ probes in Hodgkin's disease. Am J Pathol 1992; 140: 247-253.

51. Keresztes K, Miltenyi Z, Bessenyei B, et al. Association between the Epstein-Barr virus and Hodgkin's lymphoma in the North-Eastern part of Hungary: effects on therapy and survival. Acta Haematol. 2006;116 (2):101-107.

52. Dirnhofer S, Angeles-Angeles A, OrtizHidalgo $C$, et al. High prevalence of a $30-$ base pair deletion in the Epstein-Barr virus (EBV) latent membrane protein 1 gene and of strain type B EBV in Mexican classical Hodgkin's disease and reactive lymphoid tissue. Hum Pathol. 1999 Jul;30(7):781-787.

53. Peh SC, Looi LM, and Pallesen G. Epstein-Barr virus (EBV) and Hodgkin's disease in a multi-ethnic population in Malaysia. Histopathology 1997; 30: 227233. 
54. Zhou XG, Sandvej K, Li PJ, et al. Epstein-Barr virus (EBV) in Chinese pediatric Hodgkin disease: Hodgkin disease in young children is an EBVrelated lymphoma. Cancer 2001; 92(6): 1621-31.

55. Karnik S, Srinivasan B, and Nair S. Hodgkin's lymphoma: immunohistochemical features and its association with EBV LMP-1. Experience from a South Indian Hospital. Pathology 2003; 35(3):207-211.

56. Dinand V, Dawar R, Arya LS, et al. Hodgkin's lymphoma in Indian children: prevalence and significance of EpsteinBarr virus detection in Hodgkin's and Reed-Sternberg cells. Eur J Cancer 2007; 43(1):161-168.

57. Araujo I, Bittencourt AL, Barbosa HS, et al. The high frequency of EBV infection in pediatric Hodgkin lymphoma is related to the classical type in Bahia, Brazil. Virchows Arch 2006; 449 (3):315-319.

58. Takeuchi K, Morishita Y, Fukayama M, et al. Marked decrease in the Epstein-Barr virus positivity rate in nodular sclerosis subtype Hodgkin's disease in Tokyo: trend between 1955 and 1999. $\mathrm{Br} \mathrm{J}$ Haematol 2001; 113: 429-431.
59. Flavell KJ, Biddulph JP, Constandinou $\mathrm{CM}$, et al. Variation in the frequency of Epstein-Barr virus-associated Hodgkin's disease with age. Leukemia 2000; 14: 748- 753.

60. Hemsrichart $\mathrm{V}$, and Pintong J. Association of the Epstein-Barr viruses with Hodgkin lymphoma: an analysis of pediatric cases in Thailand. J Med Assoc Thai. 2005; 88(6): 782-787.

61. Tomita $\mathrm{Y}$, Ohsawa $\mathrm{M}$, Kanno $\mathrm{H}$, et al. Epstein-Barr virus in Hodgkin's disease patients in Japan. Cancer 1996; 77(1): 186-92.

62. Andriko JA, Aguilera NS, Nandedkar MA, et al. Childhood Hodgkin's disease in the United States: an analysis of histologic subtypes and association with EpsteinBarr virus. Mod Pathol 1997; 10(4):366-71. 